Extended Abstract

\title{
Translating Information
}

\section{Rafael Capurro}

${ }^{1}$ International Center for Information Ethics (ICIE), Redtenbacherstrasse 9, 76133 Karlsruhe, Germany.

E-Mail: rafael@ capurro.de

* Prof. Dr. Rafael Capurro, Redtenbacherstrasse 9, 76133 Karlsruhe, Germany; Tel.: +49-7219822922; Fax: +0049-721-9822921.

Accepted:

\section{Introduction}

This paper deals with the Arabic translation tașawwur in Averroes' Great Commentary of the term $\tau \tilde{\omega} v$

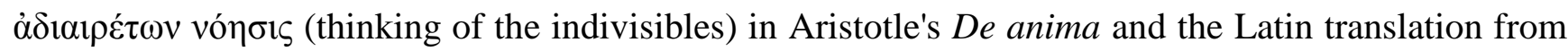
Arabic with (in-)formatio as quoted by Albertus Magnus. I briefly report on the development of the ontological (informatio materiae) and epistemological meanings of informatio in the Middle Ages as well as on the loss of the ontological meaning in Modernity. Eventually, I interpret informatio in the context of Heidegger's "hermeneutical as". In the conclusion I suggest a future research dealing with Heidegger and Mullā Sadrā and point to Barbara Cassin's concept of the "untranslatables" as a possible path of thinking concerning "Capurro's trilemma".

\section{Greek, Latin, Arabic, and Persian Roots of the Concept of Information}

For a detailed analysis of what follows see (Capurro 2014).

Tașawwur and tașdīq in Averroes' Great Commentary of Aristotle's De anima, were translated into Latin by Michael Scot with (in)formatio and fides. The first concept addresses the representation of "indivisible things" (the "ideas") while the second concept means the predicative judgement (logos apophantikos) about things using the composition of names or signs where there is right and wrong.

Informatio or just formatio or "conception" (Alain de Libera), as apposed to fides or "assentiment" (Alain de Libera) means the "thinking of the indivisible" or of the "simple objects of thought", the

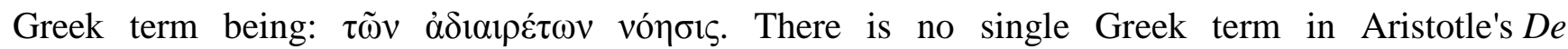


Anima corresponding to the Latin translation by Michael Scot of the Arabic term(s) used by Averroes in his Great Commentary quoted by Albertus Magnus.

Albertus Magnus (1193-1206) makes a short comment on the concept of informatio "apud Arabes" in the context of Aristotle's De anima and indirectly to Averroes, called ,the Commentator“:

"Indivisibilium quidem igitur, quae sunt incomplexa intelligentia sive intelligere, quod est actus intelligendi, in omnibus his est circa quae non est falsum, eo quod, sicut INFERIUS ostendemus, numquam accidit error intelligibilium in talium intellectu. Hic autem intellectus vocatur apud Arabes informatio, eo quod intelligere talia est informari intellectum possibilem naturis formalibus eorum."

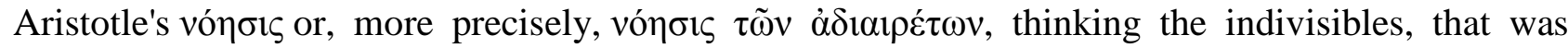
translated from Greek into Arabic with tașawwur, from Arabic into Hebrew with ziyyur, and from Arabic into Latin with (in-)formatio is an example of a complex history of translations of a Latin concept that has become paradigmatic for our age.

Throughout the Middle Ages informatio and informo are commonly used in epistemological, ontological, and pedagogical contexts by several authors (see Capurro 1978 and Capurro 2009 for details). The Aristotelian influence on the higher-level philosophical concept of informatio is shown at best in the work of Thomas Aquinas (1225-1274). Schütz (1958) distinguishes in his ThomasLexikon between informatio in the sense of "providing something with a form" in an epistemological or ontological context and the pedagogical sense of education or instruction.

Probably the most intriguing question from the point of view of the history of ideas concerns the ontological use of informatio - both in the lower-level sense of "molding matter" as well as in the higher-level sense used by Scholastics as informatio materiae - which became obsolete not only in modern languages that, like English, inherited the Latin word and slightly transformed it into information, retaining the epistemological meaning (Capurro and Hjørland 2003).

\section{Information in Modernity}

In the following I summarize some findings from (Capurro and Hjørland 2003, Capurro 2009 and Capurro 1978).

The modern uses of information show a transition period in which the medieval ontological concept of "molding matter" is not just abandoned but reshaped under empirical and epistemological premises.

The action of 'informing' with some active or essential quality" had, according to the Oxford English Dictionary "a quite restrictive use" not only in English, but also in other modern European languages, and references on "formation or molding of the mind or character, training, instruction, teaching" date from the 14th century.

This transition from Middle Ages to Modernity in the use of the concept of information - from "giving a (substantial) form to matter" to "communicating something to someone" — can be detected in the natural philosophy of René Descartes (1596-1650), who calls ideas the "forms of thought," not in the sense that these are "pictured" ("depictae") in some part of the brain, but "as far as they inform the spirit itself oriented to this part of the brain" ("sed tantum quatenus mentem ipsam in allem cerebri partem conversam informant." (Descartes 1996, VII, 161). but also, for instance, in German where the word Information was actually used in the sense of education and communication since the 15th century.Informatio was literally translated - first in a mystical context as in-Bildunge or in- 
Formunge; later on in a general pedagogical sense, such as used by Christoph Martin Wieland (17331813) - with Bildung, a term heavily charged with higher-level meaning (Capurro 1978, p. 176).

A plausible explanation for the loss of the ontological higher-level sense is the decline of Scholastic philosophy caused by the rise of modern science.

Nevertheless, the concept of information ceases to be a higher-level concept until the rise of information theory in the 20th century. Philosophers such as Francis Bacon (1561-1626), John Locke (1632-1704), George Berkeley (1685-1753), David Hume (1711-1776), and Thomas Reid (1711-1796) criticize scholastic hylomorphism and particularly the theory of abstraction.

It is interesting to observe how the concept of information is closely connected to views of knowledge. This conclusion is important with regard to the use of the concept of information in information science, because it indicates a severly neglected connection between theories of information and theories of knowledge (Capurro and Hjørland 2003).

\section{Information as Hermeneutic As}

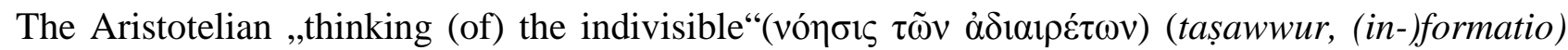
that precedes the action of the intellect dealing with the composition in predication (tașīq, fides), can be translated into Heidegger's difference between the "hermeneutical as" and the ,apophantic as.“ The philosopher and theologian Thomas Sheehan writes in his "Hermeneia and Apophansis: The early Heidegger on Aristotle":

"The noun hermeneia (or the verb hermeneuo) in Aristotle has a generic meaning and two specifications. Generically it means expression, manifestation, or communication (semainein). In increasingly determinate specification it can then mean: verbal semainein, called lexis or dialectos; and declarative verbal semainein, called apophansis or logos apophantikos.

That is: hermeneia-1 hermeneia-2 hermeneia-3 [semainein]: [legein]: [apophainesthai]:

self-expression or communication in any form;

self-expression or communication in discourse;

self-expression or communication in declarative sentences.

To synthesize is to distinguish, and the assertoric synthesis-distinction (the "apophantic as" operative in hermeneia-3) rests on the prepredicative synthesis-distinction of entities and their practical essence; and for Heidegger that composition and division is performed on the basis of the original (i.e. the hermeneutical) as. This unified as-structure, rooted in praxis, that Heidegger retrieved from Aristotle's discussion of hermeneia led to the issues of transcendence and ultimately temporality. Heidegger interpreted human beings, insofar as they already know the beingness-dimension of entities, as transcendence, i.e., as being already beyond entities and disclosive of the possibilities in terms of which entities can be understood. This kinetic exceeding of entities he called the human being's Immer-schon-vorweg-sein, his condition of being "always already ahead" of entities.

This movement is the co-performance of disclosure in humanely primordial sense, and it corresponds to the diairesis-moment of the hermeneutical as. In the oral version of his course Die Grundbegriffe der Metaphysik (February 27, 1930) Heidegger said that diairesis, seen as human transcendence, "pulls us as under, as it [p. 80] were, and grants us a stretching-ahead, takes us away into the possible... ." But at the same time the human being returns from that transcendence 
to entities so as to know them in terms of possibility, i.e., "so as to allow the possible - as what empowers the actual - to speak back to the actual in a binding way..., binding or bonding it: synthesis. Clearly the unity of diairesis as transcendence to the essence of beings and synthesis as the return to beings in their essence points to the kinetic structure that grounds the hermeneutical as, just as the hermeneutical as in turn makes possible the truth and falsehood of Aristotle's hermeneia-3." (Sheehan 2008)

In other words, the ,thinking (of) the indivisible,, that was translated into arabic as tasawwur and into Latin as „(in-formatio)“ meaning that what precedes the action of the intellect dealing with the composition and division that takes place in predication (tașdiq, fides), can be translated into Heidegger's difference between "hermeneutical as" and "apophantic as“.

\section{Conclusions}

The insight into human existence as time is metaphysically and theologically preceded by understanding humans as already being and becoming part, after death, of a divine being with or without their individuality, an issue that was and is controversial and fundamental for Greek, Latin, Arabic, Hebrew, and Persian thinkers of the Middle Ages no less than in the Islamic and Western tradition after Averroes all the way up until today.

A comparison between Mullā Sadrā (1572-1640) and Martin Heidegger seems to me an interesting topic for future research not only concerning the relation between essence and existence but also with regard to the relation between understanding and pre-understanding and tasawwur and tasdiq.

I quote from Wikipedia (Mullā Sadrā)

"Mullā Sadrā [...] was the most prominent Iranian Shia Islamic philosopher, theologian and 'A Alim who led the Iranian cultural renaissance in the 17th century. According to Oliver Leaman, Mulla Sadra is arguably the single most important and influential philosopher in the Muslim world in the last four hundred years. [...] Mullā Sadrā metaphysics gave priority "Ab initio" to existence, over quiddity. That is to say, essences are determined and variable according to existential "intensity", (to use Henry Corbin's definition), and as such essences are not immutable. The advantage to this schema is that it is acceptable to the fundamental statements of the Qur'an, even as it does not necessarily debilitate any previous Islamic philosopher's Aristotelian or Platonic foundations.“

What is information? It is one of the „untranslatables“ addressed by Barbara Cassin in her „Vocabulaire européen des Philosophies. Dictionnaire des intraduisibles“ (Paris 2004) when she writes:

„Parler d'intraduisibles n'implique nullement que les termes en question, ou les expressions, les tours syntaxiques et grammaticaux, ne soient pas traduits et ne puissent pas l'être l'intraduisible, c'est plutôt ce qu'on ne cesse pas de (ne pas) traduire. Mais cela signale que leur traduction, dans une langue ou dans l'autre, fait problème, au point de susciter parfois un néologisme ou l'imposition d'un nouveau sens sur un vieux mot: c'est un indice de la manière don't, d'une langue à l'autre, tant les mots que les réseaux conceptuels ne sont pas superposables [...]" (p. xvii-xviii)

This might be a path of thought (and action) for dealing with „Capurro“s trilemma“ as addressed by Peter Fleissner and Wolfgang Hofkirchner. 
The concept of information may have:

- The same reference in all contexts, such that qualitative changes are not grasped.

- Similar aspects between the references. In this case there a question arises about the primary or basic reference to which analogical concepts refer.

- Finally, qualitatively distinct references may exist. In this case the concepts of information are equivocal. (Fleissner and Hofkirchner 1995)

This research is not just historically relevant but also a key issue for an intercultural philosophical dialogue about the information society.

\section{Acknowledgments}

I thank Joseph Brenner for critical comments.

\section{References and Note}

The following presentation is based on my „Apud Arabes. Notes on the Greek, Latin, Arabic, and Persian Roots of the Concept of Information“ (Capurro 2014), that goes back to my $\mathrm{PhD}$ thesis "Information" (Capurro 1978), as well as on Rafael Capurro and Birger Hjørland: The Concept of Information (Capurro and Hjørland 2003) and Rafael Capurro: Past, present and future of the concept of information (Capurro 2009). References not listed can be found in these sources.

1. Capurro, R. Apud Arabes. Notes on the Greek, Latin, Arabic, and Persian Roots of the Concept of Information. 2014 http://www.capurro.de/iran.html

2. Capurro, R. Information. Munich: Saur 1978. http://www.capurro.de/info.html

3. Capurro, R. Past, present and future of the concept of information. tripleC 2009, 7, 125-141. http://www.capurro.de/infoconcept.pdf

4. Capurro, R.; Hjørland, B. The Concept of Information. In Annual Review of Information Science and Technology (ARIST), B. Cronin Ed., Information Today: Medford, New Jersey, 2003, pp. 343-411. http://www.capurro.de/infoconcept.html

5. Cassin, B. Vocabulaire européen des Philosophies. Dictionnaire des intraduisibles. Paris: Seuil, 2004.

6. Fleissner, P.; Hofkirchner, W. In-formatio revisited. Wider dem dinglichen Informationsbegriff. Informatik Forum 1995, 8, 126-131.

7. Sheehan, Th. Hermeneia and Apophansis: The early Heidegger on Aristotle. In Heidegger et l'idée de la phénoménologie, Franco Volpi et al Eds.; Dordrecht: Kluwer, 1988; pp. 67-80. https://ucursosadi.ing.uchile.cl/filosofia/2011/2/386100820/1/material_docente/previsualizar?id material $=474722$

8. Wikipedia: Mula Sadra http://en.wikipedia.org/wiki/Mulla_Sadra

(C) 2015 by the author; licensee MDPI and ISIS. This abstract is distributed under the terms and conditions of the Creative Commons Attribution license. 